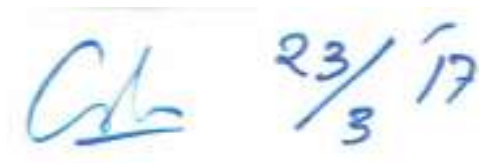

\title{
ARTIKEL
}

\section{PENGARUH MEDIA SILENT FILM TERHADAP KEMAMPUAN MENULIS NASKAH DRAMA SATU BABAK OLEH SISWA KELAS XI SMA NEGERI 11 MEDAN TAHUN PEMBELAJARAN 2016/2017}

\author{
Oleh \\ Merlin Shinta Yohana Gultom
}

NIM 2123311051

Dosen Pembimbing Skripsi

Drs. M Joharis Lubis, M.M.,M.Pd

\begin{abstract}
Telah Diverifikasi dan Dinyatakan Memenuhi Syarat untuk Diunggah pada Jurnal Online
\end{abstract}

Editor,

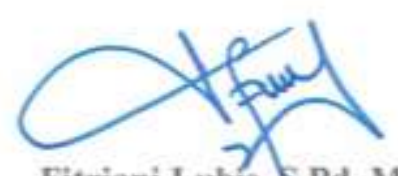

Fitriani Lubis, \$.Pd, M.Pd

NIP 197708312008122001
Medan, Maret 2017

Menyetujui:

Dosen Pembimbing Skripsi,

Drs. MJoharis Lubis, M.M., M.Pd

NIP. 196202121990031003 


\title{
PENGARUH MEDIA SILENT FILM TERHADAP KEMAMPUAN MENULIS NASKAH DRAMA SATU BABAK OLEH SISWA KELAS XI SMA NEGERI 11 MEDAN TAHUN PEMBELAJARAN 2016/2017
}

\author{
Oleh \\ Merlin Shinta Yohana Gultom \\ Drs. M Joharis Lubis, M.M.,M.Pd
}

Penelitian ini bertujuan untuk mengetahui pengaruh media Silent Film terhadap kemampuan menulis naskah drama satu babak oleh siswa kelas XI SMA Negeri 11 Medan Tahun Pembelajaran 2016/2107. Populasi dalam penelitian ini adalah semua siswa kelas XI SMA Negeri 11 Medan yang berjumlah 185 orang. Dari populasi ini diambil sampel yang terdiri dari 37 orang . Pengambilan sampel dilakukan secara acak dengan cara mengundi seluruh kelas XI SMA Negeri 11 Medan. Dan diperoleh sampel yaitu kelas XI IA 1 sebagai kelas Eksperimen dan XI IA 2 sebagai kelas Kontrol . Metode penelitian yang digunakan adalah model desain penelitian Two-Group Posttest Only Design yang hanya dilakukkan pada dua kelas. Dari pengelolahan data, diperoleh nilai tertinggi kemampuan dalam menulis naskah drama dengan menggunakan media Silent Film adalah 90 dan nilai terendah 65. Dengan demikian, nilai rata-rata kemampuan menulis naskah drama dengan menggunakan media Silent Film adalah sebesar 77 dengan kategori baik dengan simpangan baku 74 . Nilai tertinggi kemampuan menulis naskah drama satu babak dengan media konvensional 80 dan nilai terendah adalah 55 . Dengan demikian, nilai rata-rata kemampuan menulis naskah drama 68 dengan kategori cukup dan simpangan baku sebesar 7,67 Adapun perbedaan hasil belajar menulis naskah drama satu babak dengan menggunakan media Silent Film dan tanpa menggunakan media film dalam meningkatkan kemampuan menulis naskah drama. Hasil peningkatan menulis naskah drama satu babak dengan media Silent Film lebih baik dibandingkan dengan hasil peningkatan menulis naskah drama satu babak tanpa menggunakan media film.

Kata Kunci : Silent Film, Kemampuan menulis, Naskah drama satu babak 


\section{PENDAHULUAN}

Pembelajaran bahasa mencakup empat aspek keterampilan berbahasa yaitu, mendengarkan atau menyimak, membaca, menulis, dan berbicara. Keempat aspek tersebut saling berkaitan satu sama lain Tarigan 1986:1. Keterampilan menulis adalah menuangkan pikiran atau perasaan melalui tulisan, mempergunakan bahasa sebagai medianya. Hasil keterampilan menulis dibaca oleh orang lain. Agar tulisan itu mudah dipahami, maka tulisan harus menggunakan bahasa yang jelas. Oleh karena itu, keterampilan menulis membutuhkan keseriusan dan kesungguhan dalam pembelajarannya.

Berdasarkan hasil wawancara dengan guru bidang studi Bahasa Indonesia, Ida Pane S.Pd pada tanggal 21 November 2017, dapat dikatakan bahwa pembelajaran sastra, khususnya menulis naskah drama di SMA Negeri 11 Medan, masih belum mencapai nilai KKM . Dalam wawancara tersebut guru juga mengatakan bahwa ada beberapa kendala yang di hadapi siswa ketika dihadapkan dengan pelajaran sastra salah satunya menulis naskah drama. Pertama, kurangnya pengetahuan siswa terhadap pelajaran sastra. Kedua, masih rendahnya terampilan siswa dalam menulis naskah drama. Ketiga, siswa kesulitan dalam merangkai katakata ketika menulis dialog drama. Keempat, model pembelajaran dari guru yang kurang efektif. Kurikulum KTSP juga menuntut siswa mampu menulis naskah drama, sedangkan kemampuan menulis naskah drama siswa masih rendah. Jadi dapat

di simpulkan bahwa hanya ada beberapa kelas yang mencapai nilai tuntas dalam materi menulis naskah drama.

Penelitian tentang pembelajaran menulis naskah drama juga pernah dilakukan oleh Putu Ari Utama Irawan dengan judul Penggunaan Film Bisu Dengan Teknik Dubbing Untuk Meningkatkan Kemampuan Menyampaikan Dialog Dalam Drama Siswa Kelas XI IPA 1 Di SMA Negeri 2 Negara.

Hasil penelitian ini adalah (1) terdapat beberapa langkah-langkah pembelajaran yang efektif melalui penggunaan film bisu dengan teknik dubbing untuk meningkatkan 
kemampuan menyampaikan dialog dalam drama. Langkah-langkah tersebut menekankan pada pemberian contoh penyampaian dialog oleh guru, latihan berulangulang, dan pemberian penghargaan. (2) adanya peningkatan dan ketuntasan hasil belajar menyampaikan dialog dalam drama berkat diterapkannya film bisu dengan teknik dubbing, yakni pada data awal skor rata-rata klasikal 64 dengan kategori cukup, siklus I memperoleh skor rata-rata klasikal 76 dengan ketegori baik, sedangkan pada siklus II nilai rata-rata klasikal siswa menjadi 80,90 dengan kategori baik, dan (3) siswa memberikan respons positif terhadap penggunaan film bisu dengan teknik dubbing dalam pembelajaran menyampaikan dialog dalam drama. Berdasarkan hasil penelitian ini, guru disarankan menggunakan media berupa film bisu dengan teknik dubbing ini untuk pelajaran yang menuntut keterampilan, khususnya menyampaikan dialog dalam drama.

Amsal (2012) mengungkapkan bahwa silent film adalah film yang dibuat tanpa adanya suara terutama dalam dialog dan penonton "dituntut" untuk memahami alur cerita itu melalui gerakan tubuh dari pemain film. Karena yang dapat dilihat dan dinikmati adalah visual dari film tersebut. Gerakan-gerakan pelakulah yang akan memberi cerita. Sementara itu Arsyad (2010) mengungkapkan bahwa film dapat mendorong dan meningkatkan motivasi, bahkan menanamkan sikap dan segi-segi afektif lainnya.

Pembelajaran menulis naskah drama disini menggunakan media silent film. Alasan saya memilih silent film ini karena mempertimbangkan kesesuaian film dengan judul saya yang membahas tentang kemampuan menulis naskah drama satu babak. Silent film memiliki urutan peristiwa yang jelas, dalam menulis naskah drama urutan peristiwa merupakan hal yang penting bagi pengarang dalam menyampaikan dialog agar sesuai dengan alur. Silent film merupakan film tanpa suara, jadi dialog dalam silent film dihilangkan. Sedangkan dalam pembuatan naskah drama dialog merupakan hal pokok. Dengan melihat silent film peserta didik atau sasaran 
diharapkan mampu menerka atau membuat naskah drama berdasarkan film yang telah mereka lihat.

Berdasarkan uraian dan masalah diatas, maka penulis tertarik untuk melihat sejauh mana pengaruh media silent film terhadap kemampuan siswa dalam menulis naskah drama oleh siswa kelas XI SMA Negeri 11 Medan Tahun Pembelajaran $2016 / 2017$.

\section{METODE PENELTIAN}

Penelitian adalah suatu proses yaitu rangkaian kegiatan yang dilakukan secara terencana dan sistematis. Dalam suatu penelitian, metode memegang peranan yang sangat penting. Hal ini disebabkan karena semua kegiatan yang akan dilakukan dalam penelitian sangat bergantung pada metode yang digunakan.

Pelaksanaan metode yang digunakan dalam penelitian ini adalah metode eksperimen dengan Two-Group Post-test Only Design. Metode ini dipergunakan karena penelitian ingin menggambarkan hasil belajar siswa dengan menngunakan Media silent film dalam menulis naskah drama satu babak.

Peneliti memberi test awal atau post-test (X) kepada siswa kemudian memberikan perlakuan kepada siswa dengan mengajarkan materi menulis cerpen dengan menggunakan media silent film (Film Bisu ), setelah itu memberi test lagi sebagai post test (Y) tanpa menggunakan media film. Kemudian, dilihat perbedaan hasil belajar siswa sebelum mendapat perlakuan dengan setelah mendapat perlakuan. Penelitian ini bertujuan untuk mengetahui adanya pengaruh penggunaan media pembelajaran silent film terhadap kemampuan menulis naskah drama satu babak oleh siswa kelas XI SMA Negeri 11 Medan Tahun Pembelajaran 2016/2017. Data yang diperoleh selanjutnya dianalisis secara statistik dengan langkah-langkah analisis yaitu data hasil post-test disusun dalam bentuk tabel, menentukan nilai rata-rata dan standar deviasi dari kedua data sampel, menghitung uji normalitas, uji homogenitas, danuji hipotesis.Setelah t diketahui maka nilai tersebut akan dikonsultasikan dengan tabel pada taraf signifikansi $5 \%$ dengan derajat kebebasan $(\mathrm{dk})=\mathrm{n}-1$ pada taraf nyata 
$\alpha=0,05$. Dengan demikian, jika $\mathrm{t}_{\mathrm{o}}<\mathrm{t}_{\mathrm{t}}$ pada taraf nyata $\alpha=0,05$ maka Ho diterima dan Ha ditolak sebaliknya jika $\mathrm{t}_{\mathrm{o}}>\mathrm{t}_{\mathrm{p}}$ ada taraf nyata $\alpha=0,05$ maka Ho ditolak dan $\mathrm{Ha}$ diterima.

\section{HASIL PENELITIAN DAN PEMBAHASAN}

\section{Hasil Penelitian}

1. Kemampuan Menulis Naskah Drama Satu Babab Tanpa Menggunakan Media Film Oleh Siswa Kelas XI SMA Negeri Medan Tahun Pembelajaran 2016/2017.

Kemampuan menulis naskah drama satu babak tanpa menggunakan media film termasuk dalam lima kategori, yaitu kategori sangat baik $0 \%$, kategori baik sebanyak 11 orang atau 30\%, kategori cukup sebanyak 19 orang atau 51\%, kategori kurang sebanyak 7 orang atau 19\%, dan kategori sangat kurang sebanyak 0\%.Kemampuan menulis naskah drama satu babak tanpa menggunakan media film diperoleh nilai ratarata 68 dan berada pada kategori cukup. Dengan nilai tertinggi 80 dan nilai terendah 55.

\section{Kemampuan Menulis Naskah Drama Satu Babab Menggunakan Media Silent Film Oleh Siswa Kelas XI SMA Negeri Medan Tahun Pembelajaran 2016/2017.}

Kemampuan menulis naskah drama satu babak menggunakan media silent film termasuk dalam lima kategori, yaitu kategori sangat baik sebanyak 10 orang atau $27 \%$, kategori baik sebanyak 16 orang atau 43\%, kategori cukup sebanyak 11 orang atau 30\%, kategori kurang sebanyak 0\%, dan kategori sangat kurang sebanyak 0\%.Kemampuan menulis naskah drama satu babak menggunakan media silent film diperoleh nilai rata-rata 77 dan berada pada kategori baik. Dengan nilai tertinggi 90 dan nilai terendah 65 . 


\section{Perbandingan Hasil Penilaian tanpan media film dan menggunakan media silent film Oleh Siswa Kelas XI SMA Negeri 11 Medaan Tahun Pembelajaran 2016/2017.}

Perbandingan tanpa menggunakan media dan menggunakan media silent film di atas dapat kita lihat perbandingan nilai masing-masing siswa.Dari 74 siswa semua nilai siswa mengalami kenaikan. Kenaikan terjadi pada tahap tana menggunakan media dan menggunakan media silent film yang berkategori cukup dengan nilai ratarata 68 dibandingkan dengan tahap setelah menggunakan media silent film yang berkategori baik dengan nilai rata-rata 77 . Hal ini berarti media silent film yang digunakan dalam pengajaran menulis naskah drama satu babak sangatlah berpengaruh.

\section{Pembahasan Hasil Penelitian}

Pelaksanaan metode yang digunakan dalam penelitian ini adalah metode eksperimen dengan Two-Group Post-test Only Design. Metode ini dipergunakan karena penelitian ingin menggambarkan hasil belajar siswa dengan menngunakan Media silent film dalam menulis naskah drama satu babak. Sampel adalah sebagian dari populasi. Purposive sampling adalah tehnik pengambilan sampel bertujuan dengan cara mengambil subjek bukan didasarkan strata, random atau daerah tertentu tetapi didasarkan atau adanya tujuan tertentu ( Arikunto 2006 ).

Pembelajaran menulis naskah drama satu babak yang telah dibahas sebelumnya, nilai rata-rata kemampuan menulis naskah drama siswa tanpa menggunakan media film, yaitu 68 dengan kategori cukup,selain itu apabila ditinjau dari KKM (Kriteria Ketuntasan Minimal), maka nilai rata-rata menulis naskah drama siswa termasuk kategori tidak tuntas karenaskah drama satu babak siswa menggunakan media silent film, yaitu 77 dengan kategori baik, selain itu apabila ditinjau dari KKM (Kriteria Ketuntasan Minimal), maka nilai rata-rata menulis naskah drama siswa termasuk kategori tuntas karena berada di atas nilai 75 . 
Media pembelajaran silent film efektif digunakan dalam meningkatkan kemampuan menulis naskah drama satu babak, hal ini terlihat pada perbedaaan nilai menulis naskah drama siswa tanpa mengunakan media film dan mengunakan media silent film. Dengan demikian, dapat disimpulkan bahwa pembelajaran dengan menggunakan media silent film berpengaruh dalam meningkatkan kemampuan menulis naskah drama satu babak siswa .

\section{Kemampuan Menulis Naskah Drama Satu Babab Tanpa Menggunakan Media Film Oleh Siswa Kelas XI SMA Negeri Medan Tahun Pembelajaran 2016/2017.}

Berdasarkan indikator penilaian menulis naskah drama satu babak yang telah

dibahas sebelumnya, hasil belajar menulis naskah drama satu babak siswa tanpa menggunakan media film berada dalam kategori cukup dengan nilai rata- rata 68 . Kemampuan ini berada di bawah KKM (Kriteria Ketuntasan Minimal ) yang sudah ditetapkan yaitu 75 .

Sebagaimana disajikan pada hasil penelitian, bahwasanya hal ini sesuai dengan penelitian yang dilakukan Selvia Milawati (2012: 4) dalam jurnal yang berjudul “Peningkatan Kemampuan Menulis Naskah Drama Dengan Strategi Sinektik (Model Gordon Plus) Pada Siswa Kelas XI IS 2 SMA Negeri 8 Malang”

terdapat 31 siswa dari 37 siswa atau $83,78 \%$ yang nilainya belum mencapai KKM. Adapun rata-rata nilai siswa dalam kelas XI IS 2 SMA Negeri 8 Malang adalah 49,98. Oleh karena itu, kemampuan menulis naskah drama dalam mendeskripsikan perilaku manusia perlu diperbaiki atau ditingkatkan. Dalam siklus I diperoleh hasil siswa yang memenuhi KKM (Kriteria Ketuntasan Minimal) pada siklus I ini terdapat 15 siswa atau 40,54\%. Sedangkan yang belum memenuhi KKM (Kriteria Ketuntasan Minimal) sebanyak 22 siswa atau 59,46\%.

Pada hasil kemampuan menulis tanpa menggunakan media film dalam pembelajaran menulis naskah drama satu babak terlihat siswa belum optimis dalam mengeksplorasi kemampuannya dalam memahami menulis naskah drama satu babak dari aspek tema,plot,penokohan,dialog,latar,amanat. Hal tersebut dikarenakan siswa 
hanya mendengarkan dan menerima penjelasan guru secara satu arah. Siswa hanya mampu menyerap sedikit informasi tanpa mencari informasi tambahan dari sumber belajar yang tersedia. Pada saat pembelajaran guru memberikan penuturan secara lisan kepada sejumlah siswa, akibatnya siswa kurang aktif dan kurang kreatif dalam menerima materi pembelajaran dan siswa masih terbatas dalam memperoleh pengetahuan tentang materi menulis naskah drama satu babak.

\section{Kemampuan Menulis Naskah Drama Satu Babab Menggunakan Media Silent Film Oleh Siswa Kelas XI SMA Negeri Medan Tahun Pembelajaran 2016/2017.}

Berdasarkan indikator penilaian menulis naskah drama siswa yang telah dibahas sebelumnya, hasil belajar menulis naskah drama satu babak siswa dengan menggunakan media silent film berada dalam kategori baik dengan nilai rata-rata 77 . Kemampuan ini sudah mencapai KKM ( Kriteria Ketuntasan Minimal ) yang sudah di tetapkan dalam menulis naskah drama satu babak yaitu 75. Pada hasil dengan menggunakan media silent film terlihat siswa menjadi lebih optimis mengeksplorasi kemampuannya dalam memahami menulis naskah drama satu babak dari aspek tema,plot,penokohan,dialog,latar,amanat. Pengunaan media silent film dalam

pembelajaran membuat siswa lebih antusias dalam belajar sehingga siswa lebih aktif dan kreatif untuk berfikir logis,kriti, dan analisis. Oleh karena itu, nilai kemampuan menulis naskah drama satu babak dengan menggunakan media silent film mengalami peningkatan yang signifikan.

\section{Pengaruh Media Silent Film Terhadap Kemampuan Menulis Naskah Drama Satu Babak Oleh Siswa Kelas XI SMA Negeri 11 Medan Tahun Pembelajaran 2016/2017}

Sebagaimana disajikan pada hasil penelitian yang menunjukan nilai ratarata untuk kemampuan menulis naskah drama satu babak pada tahap tanpa menggunakan media film tergolong pada kategori cukup dengan nilai rata-rata 68 dibandingkan dengan tahap setelah menggunakan media silent film yang berkategori 
baik dengan nilai rata-rata 77 . Sehingga dari data tersebut dapat ditemukan bahwa penggunaan media silent film berpengaruh dalam meningkatkan kemampuan menulis naskah drama satu babak. Hal ini dikarenakan pembelajaran dengan menggunakan media silent film ditujukan untuk meningkatkan efektifitas dan efisiensi proses belajar mengajar, sehingga daya nalar serta daya rekamnya berkembang, selain itu pengunaan media silent film menekankan pada proses berpikir kritis dan analitis untuk mencari dan menemukan sendiri dari jawaban dari suatu masalah yang dipertanyakan sehingga siswa menjadi lebih kreatif dan aktif dalam menerima materi pelajaran.

Perhitungan nilai pada deskripsi data, kemampuan menulis naskah drama satu babak dengan menggunakan media silent film kategori baik 10 siswa atau $27 \%$, kategori baik sebanyak 16 siswa atau 43\%, kategori cukup sebanyak 11 siswa atau $30 \%$. Identifikasi ini termasuk normal dan wajar karena yang paling banyak adalah kategori baik. Jadi menulis naskah drama dengan menggunakan media silent film ini berhasil diterapkan kepada siswa.

Sementara, kemampuan menulis naskah drama tanpa menggunakan media film termasuk kedalam kategori baik sebanyak 11 siswa atau 30\%, kategori cukup ada sebanyak 19 siswa atau $51 \%$, kategori kurang sebanyak 7 siswa atau $19 \%$. Identifikasi ini termasuk normal dan wajar karena kategori yang paling banyak adalah cukup . Dengan demikian dapat dapat di ketahui bahwa menulis naskah drama satu babak tanpa mengunakan media film perlu dipertimbangkan dalam pembelajaran selanjutnya.

Hal itu pula yang menunjukan bahwa media silent film lebih efektif karena media silent film mampu menciptakan lingkungan belajar yang membuat siswa merasa aktif dalam belajar dan siswa termotivasi untuk mengikuti pelajaran . Media silent film mampu membuat siswa menggali sendiri pemahaman mereka tentang menulis naskah drama satu babak. Dan kegiatan ini juga melibatkan siswa secara langsung dimana mereka dapat mengukur kemampuan menulis mereka sendiri. 


\section{PENUTUP}

Berdasarkan hasil penelitian yang telah diuraikan pada BAB IV, maka dapat disimpulkan : Nilai tertinggi kemampuan dalam menulis naskah drama dengan menggunakan media silent film adalah 90 dan nilai terendah 65. Dengan demikian, nilai rata-rata kemampuan menulis naskah drama dengan menggunakan media silent film adalah sebesar 77 dengan kategori baik dengan simpangan baku 74. Nilai tertinggi kemampuan menulis naskah drama satu babak tanpa menggunakan media film 80 dan nilai terendah adalah 55. Dengan demikian, nilai rata-rata kemampuan menulis naskah drama 68 dengan kategori cukup dan simpangan baku sebesar 7,67. Adapun perbedaan hasil belajar menulis naskah drama satu babak dengan menggunakan media silent film dan tanpa menggunakan media film dalam meningkatkan kemampuan menulis naskah drama. Hasil peningkatan menulis naskah drama satu babak dengan media silent film lebih baik dibandingkan dengan hasil peningkatan menulis naskah drama satu babak tanpa menggunakan media film

\section{DAFTAR PUSTAKA}

Amsal, Andi Yasir. 2012. "Film Bisu sebagai Salah Satu Media Pembelajaran”. http://andiyasiramsalmediapembelajaran.blogspot.com/2016/01/film-bisu-

Arikunto, Suharsim. 2006 . Prosedur Penelitian. Jakarta : Rinaka Cipta.

Arsyad, Azhar. 2010. Media Pembelajaran. Jakarta: PT. Raja Grafindo.

Hamalik, O, (1994) Media Pendidikan, cetakan ke-7. Bandung: Penerbit PT. Citra Aditya Bakti.

Kosasih, E. 2003. Kompetensi Ketatabahasaan dan Kesusastraan Cermat Berbahasa Indonesia. Bandung: Yrama Widya.

Tarigan, Henry Guntur. 1984. Menulis Suatu Keterampilan Deskriptif. Bandung. 